$A 10.12 / 3: 22$

PORTO RICO AGRICULTURAL EXPERIMENT STATION,

D. W. MAY, Agronomist in Charge.

Mayaguez, P. R.

Bulletin No. 22

EFFECT OF

DIFFERENT NETHODS OF TRANSPLANTING COFFEE.

BY

T. B. MoCLELLAND

Assistant Horticulturist DOCUMENTS DEPT

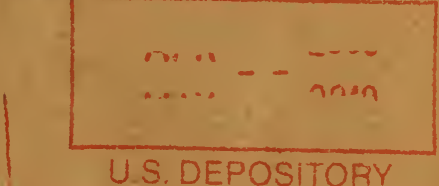

US. DEPOSITORY

UNDER THE SUPERVISION OF STATES RELATIONS SERVICE, Office of Experiment Stations, C. S. DEPARTMENT OF AGRICULTURE.

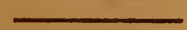

(n)

WASHINGTON:

GOVERNMENT PRINTING OFFICE.

1917. 


PORTO RICO AGRICULTURAL EXPERIMENT STATION,

D. W. MAY, Agronomist in Charge.

Mayaguez, P. R.

Bulletin No. 22

\title{
EFFECT OF
}

\section{DIFFERENT METHODS OF TRANSPLANTING COFFEE.}

$\mathrm{BY}$

\author{
T. B. MCCLELLAND
}

Assistant Horticulturist

UNDER THE SUPERTISION OF STATES RELATIONS SERVICE, Office of Experiment Stations, J. S. DEPARTMENT OF AGRICULTURE. 


\section{PORTO RIC0 AGRICULTURAL EXPERIMENT STATION.}

[Lnder the supervision of A. C. True, Director of the States Relations Service, United States Department of Agriculture.]

E. W. Allen, Chief of Office of Experiment stations.

IValter H. Evaxs, Chief of Division of Insular Stations, Office of Experimeint Stations.

\section{STATION STAFF.}

D. W. MAY, Agronomist in Charge.

P. L. GILE, Chemist.

C. F. Kinman, Horticulturist.

R. H. Van Zwaluwenburg, Entomologist.

E. W. Brandes, Plant Pathologist.

T. B. MCClelland, Assistant Horticulturist.

J. O. Carrero, Assistant Chemist.

H. C. Henricksen, Assistant in Extension Work.

W. A. MACE, Assistant in Extension Work.

C. Alemar, Jr., Clerk.

\section{LETTER OF TRANSMITTAL.}

\section{Porto Rico Agricultural Experiment Station, Mayaguez, P. R., January 30, $191 \%$.}

SrR: I have the honor to submit herewith a manuscript on Effect of Different Methods of Transplanting Coffee, by T. B. McClelland, assistant horticulturist.

The unusually favorable results secured by the improved methods of transplanting coffee warrant the dissemination of this knowledge as widely as possible among coffee planters. It is believed that the procedure suggested, which can be easily carried out by any planter, will yield large returns on the labor expended.

I respectfully recommend that the manuscript be published as Bulletin No. 22 of this station.

Respectfully,

D. W. MAY, Agronomist in Charge.

Dr. A. C. True,

Director States Relations Service,

United States Department of Agriculture, Washington, D. C.

Recommended for publication.

A. C. True, Director.

Publication authorized.

D. F. Houston,

Secretary of Agriculture. 


\section{EFFECT OF DIFFERENT METHODS OF TRANS. PLANTING COFFEE.}

CONTENTS.

Introduction

Page.

3 Summary of the results of the tests

Page.

Tests of different methods of transplanting -

\section{INTRODUCTION.}

In a previous publication of this station ${ }^{1}$ it was suggested as adrisable to select seed from rigorous trees and to make nurseries for the production of rigorous seedlings, rather than to follow the almost universal practice of using chance seedlings from any source whatever. The proper selection of the seed and the care of the young plants in the nursery should be the first considerations in the development of a plantation. The land having been properly prepared, remoring the seedlings from the nursery and setting them in the permanent location are next in their effect on the growth and vigor of the trees.

Nearly all kinds of plants can be transplanted, but they rary. greatly in the rapidity of their recovery from this operation, which usually destroys a considerable part of the root system and, by severing the connection between the plant and the soil, temporarily arrests derelopment. In some plants this recovery is so difficult as practically to prohibit transplanting. The general practice in transplanting coffee has been to pull out or dig out without any adhering soil a young tree sereral feet high with little care as to how many small roots were broken off and to transplarit with no leaf pruning. This results in a serere retardation of growth or even the loss of the tree.

The object of this publication is to report the result of a trial test showing the adrantages and disadrantages of different methods of transplanting when applied to coffee culture, and to help correct the bad practice just mentioned.

TESTS OF DIFFERENT METHODS OF TRANSPLANTING.

PLANTING No. 1.

Location.-As the location for testing the effect of different methods of transplanting on the early derelopment of the coffee

${ }^{3}$ Porto Rico Sta. Circ. 15 (1912). 
tree, two hillsides meeting in a small valley bottom were selected. The rows were made down one slope and up the other, being very uniform as to their proportion of good and poor soil and quite typical of coffee land. Twenty-one trees were set in each row. All seedlings were of the same age and from the 1908 crop of one variety of Arabian coffee. Large holes were opened up and filled with surface soil previous to setting the trees.

Transplanting seedlings with five to six pairs of leaves.-Rows 1, 2, and 3 were set in August. 1909, the young trees having then five to six pairs of true leaves. The plants for row 1 were removed from the nursery with as large a clod of earth surrounding the roots as the spacing in the nursery permitted, the bed being cut with a - machete into squares approximately 6 inches across. The heary texture of the clay ${ }^{1}$ allowed these blocks of soil to be easily lifted without crumbling. They were then slightly pressed to prevent breaking and laid in a box to be carried to the plat. With five or six pairs of leaves developed the roots were nearly all contained in clods of the size used. The plants were' set immediately to the same depth as in the nursery, and the earth was well firmed around them.

Rows 2 and 3 were set with plants having the root systems bare of earth. The upper leaves were slightly pruned to prevent top-heariness. Care was taken in remoring the plants from the nursery to avoid as much as possible any damage to the roots. As the taproots in most instances were badly curled and twisted, those of the plants for row 2 were clipped just above the twist, generally about an inch below the root collar, in order to force straight growth. The few straight taproots were clipped where they bent easily, while the side roots were lightly pruned. For row 3 the roots were left unpruned. The plants were set to the same depth as in the nursery and the earth carefully filled in around the roots.

For the first few months after transplanting row 1 seemed slightly more vigorous than row 3 . At one year from setting no difference in vigor could be noted between rows 1 and 3 , but both were superior to row 2 , the trees of which had been severely root-pruned. From row 1 two trees had died; from row 2 , six trees; and from row 3 , three trees. Of the trees with sererely pruned roots more than twice as many were lost the first year as of the corresponding trees with unpruned roots.

The condition of the trees at the end of the first year indicated that when seedlings with five to six pairs of leaves are transplanted, as good results may be had from careful transplanting with the root system bare of earth as with the roots incased in a ball of earth from the nursery. a process involving more labor. 
Transplanting older seedlings.-In Iugust, 1910, six additional rows were set with plants which had been left in the nursery a year longer than those in the previous experiment. The average plant had from two to four pairs of branches. The manner of transplanting was the same as that of the year previous. The trees for row 4 were removed from the nursery with a large ball of earth. The increased extension of the root system necessitated the clipping of some roots. The plants of rows 5 and 6 were set with roots bare of earth, those of row $\check{5}$ sererely cut back, and of row 6 as nearly intact as possible. On one hillside the trees of these three rows had the leafage reduced by cutting a way one-half to two-thirds of each leaf, but this leaf pruning showed no measurable effect on the growth at the end of a year, the two groups varying only 0.4 inch in arerage height per tree.

The root treatment of rows 7,8 , and 9 corresponded to that of rows 4,5 , and 6 , respectively, but their stems were all cut at a height of 4 to 6 inches.

As the root pruning given rows 2,5 , and 8 was due to an abnormal condition, these rows should be considered in a separate group. In transplanting older seedlings in these tests, and in other instances since, it has been observed that many trees with a badly twisted taproot will send down a strong; straight root from above the twist, thus remedying the trouble without aid. The rery radical pruning of rows 7,8 , and 9 also puts these rows in a class to themselves.

Two months after setting all rows looked thriftier than those with severely pruned roots. Most of the stumps of rows 7,8 , and 9 had developed shoots 2 inches high. At 4 months after setting the trees which had been transplanted with a ball of earth looked more vigorous than those in the corresponding rows set with trees with bare roots.

Table I gives the growth and production of the trees in 1911 and 1912 :

TABLE I.-Growth and produrtion of trees in planting No. 1.

\begin{tabular}{|c|c|c|c|c|c|c|c|c|}
\hline \multirow{2}{*}{ Row. } & \multirow{2}{*}{ Date of transplanting. } & \multirow{2}{*}{$\begin{array}{l}\text { Treat- } \\
\text { ment.1 }\end{array}$} & \multicolumn{2}{|c|}{$\begin{array}{c}\text { Number of living } \\
\text { trees. }\end{array}$} & \multicolumn{2}{|c|}{$\begin{array}{l}\text { A verage height } \\
\text { per tree. }\end{array}$} & \multirow{2}{*}{$\begin{array}{c}\text { Number } \\
\text { of pro- } \\
\text { ducing } \\
\text { trees, } \\
1911 .\end{array}$} & \multirow{2}{*}{$\begin{array}{l}\text { Total } \\
\text { yield of } \\
\text { coffee } \\
\text { cherries } \\
1912 .\end{array}$} \\
\hline & & & $\begin{array}{l}\text { August, } \\
1911 .\end{array}$ & $\begin{array}{l}\text { Septem- } \\
\text { ber, } 1912 .\end{array}$ & $\begin{array}{l}\text { August, } \\
1911 .\end{array}$ & $\begin{array}{l}\text { Septem- } \\
\text { ber, } 1912 \text {. }\end{array}$ & & \\
\hline $\begin{array}{l}1 \\
2 \\
3 \\
4 \\
5 \\
6 \\
7 \\
8 \\
9\end{array}$ & 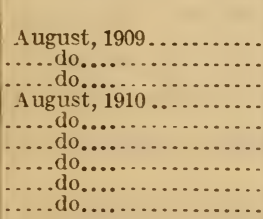 & 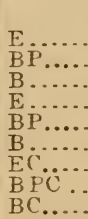 & $\begin{array}{l}17 \\
12 \\
15 \\
21 \\
20 \\
21 \\
19 \\
15 \\
16\end{array}$ & $\begin{array}{l}17 \\
11 \\
18 \\
21 \\
17 \\
19 \\
18 \\
12 \\
14\end{array}$ & $\begin{array}{r}\text { Inches. } \\
33.6 \\
31.9 \\
34.7 \\
42.0 \\
34.2 \\
31.1 \\
17.4 \\
11.7 \\
13.3\end{array}$ & $\begin{array}{r}\text { Inches. } \\
62.0 \\
65.4 \\
61.4 \\
71.5 \\
64.4 \\
57.9 \\
39.8 \\
33.5 \\
35.7\end{array}$ & $\begin{array}{l}6 \\
4 \\
5 \\
5 \\
0 \\
0 \\
0 \\
0 \\
0\end{array}$ & $\begin{array}{r}\text { Quarts. } \\
14.8 \\
12.7 \\
16.9 \\
17.9 \\
8.4 \\
8.9 \\
1.0 \\
.2 \\
.3\end{array}$ \\
\hline
\end{tabular}

${ }_{1} \mathrm{E}$, roots in ball of earth; $\mathrm{B}$, roots bare cf earth; $\mathrm{P}$, roots severely pruned; $\mathrm{C}$, stems cut at height of 4 to 6 inches. 
By August, 1911, rows 1, 2, and 3 had lost 16 trees, while rows 4, 5 , and 6 had lost only one. This indicated that a more even stand might be obtained by leaving the trees in the nursery until the second summer after planting than by setting out small seedlings with five to six pairs of leaves. In September, 1912, row 4 was the only one which had lost no trees.

In August, 1911, the arerage height per tree for row 4 was 7.3 inches greater than that of the next tallest row and 10.9 inches greater than the average height of the trees of row 6 , set at the same time but with the roots bare of earth. When considered at this time, in lines transverse to the rows and to the slope of the hill, 43 of the 56 living trees of rows 1, 3, and 6 were shorter than the correspondingly placed trees of row 4. Measurements made in September, 1912, showed the average height per tree of row 4 to be 13.6 inches greater than the arerage height per tree for row 6 .

In 1911 four to six trees in each of rows 1 to 4 produced some coffee, but no other trees in the planting gave any crop. This indicated that early production can be secured either by setting quite young plants or by transplanting older ones with a ball of earth incasing the roots. While the arerage yield per tree in 1912 for rows 1 and 3 exceeded that of row 4 , the total yield of row 4 was the greatest of any row and doubled that of row 6 .

In transplanting trees about 20 months old, as in this instance, better development and earlier yield can be secured by moving the plants with the roots incased in a ball of earth. Transplanting seedlings a year younger than these necessitates caring for the plantation for an additional year, a much more costly proceeding than keeping the nursery in condition. Also, the rery small trees, less able to cope with adverse conditions, are more apt to be lost, learing spaces to be refilled.

The slight growth and meager crop of rows 7,8 , and 9 show these trees to have been retarded in their development a full year by the cutting back of the young trees to 4 to 6 inch stumps on transplanting.

PLANTING NO. 2.

As a check on rows 4 and 6 of the preceding test, each of two small beds in a location shown by the growth of near-by coffee trees to be well adapted to this crop was set with 10 trees of Arabian coffee from seed planted a little more than 21 months before. In each bed five trees were set with roots in a clod of soil from the nursery and five with roots bare of earth. Is the trees were to be left only a short time, a close planting with consequent uniform conditions was possible.

The combined height at the time of setting of the 10 trees transplanted with roots incased in soil was $306 \frac{1}{2}$ inches, and that of the 
10 trees transplanted with roots bare of soil, 313 inches. Six months later the former measured 421 inches in height, the latter $38 \pm \frac{1}{2}$ inches, an increase of $114 \frac{1}{2}$ inches for those transplanted with roots in the block of soil from the nursery, but only $71 \frac{1}{2}$ inches for the trees transplanted with roots bare of soil. At the end of a year the former had increased in height $252 \frac{1}{2}$ inches and the latter 226 inches, an 11.7 per cent greater gain for the trees transplanted with their roots incased in soil.

At 18 months from transplanting, although three trees of each group were vielding nothing, the remaining seren trees of those set with clods were producing 352 drupes, as compared with 115 drupes from the seren check trees, the first rield from the trees set with soil-incased roots being three times as great as that from the trees set with bare roots.

PLANTING No. 3.

Balled $v$. bare roots for transplanting.-To test the two methods on a larger scale, 321 trees of San Ramon coffee from seeds planted in February. 1913, were set in 34 rows, August 10-11, 1914. To make the conditions of the experiment uniform alternate rows were used to form the two groups, group 1 consisting of trees remored from the nursery with balled roots and unpruned leares, and group 2 of trees with bare roots and half of the foliage remored. The latter were carried from the nursery to the field in dampened sacks to prevent wilting. Rain soon followed the transplanting, and conditions were very farorable.

San Ramon is a coffee of a more dwarfed and stocky habit of growth than the typical Porto Rican coffee. This varietal difference accounts for the much slower increase in height of San Ramon. The comparative differences, however, between the two groups of the experiment are very marked.

Measurements of the height of the trees were made at regular intervals during the two years of the test, and the results are shown in the following table:

TAElE II.-Turo year's grouth of San Ramon coffee.

\begin{tabular}{|c|c|c|c|c|c|c|}
\hline & \multicolumn{5}{|c|}{ A rerage height per tree. } & \multirow{2}{*}{$\begin{array}{l}\text { Increase } \\
\text { in } \\
\text { average } \\
\text { height in } \\
\text { two years. }\end{array}$} \\
\hline & Aug. 19, & $\begin{array}{c}\text { Feb. 19, } \\
1915 .\end{array}$ & $\begin{array}{l}\text { Aug. } 18, \\
1915 .\end{array}$ & $\begin{array}{l}\text { Feb. 19, } \\
1916 .\end{array}$ & $\begin{array}{l}\text { Aug. 18, } \\
1916 .\end{array}$ & \\
\hline $\begin{array}{l}\text { Group } 1 \ldots \\
\text { Group } 2 . .\end{array}$ & $\begin{array}{r}\text { Inches. } \\
18.5 \\
19.9\end{array}$ & $\begin{array}{r}\text { Inches. } \\
23.0 \\
21.2\end{array}$ & $\begin{array}{r}\text { Inches. } \\
29.5 \\
25.0\end{array}$ & $\begin{array}{r}\text { Inches. } \\
33.1 \\
28.3\end{array}$ & $\begin{array}{r}\text { Inches. } \\
41.6 \\
36.0\end{array}$ & $\begin{array}{r}\text { Inches. } \\
23.1 \\
16.1\end{array}$ \\
\hline Difference in favor of group $1 \ldots$ & -1.4 & +1.8 & +4.5 & +4.8 & +5.6 & $+\pi .0$ \\
\hline
\end{tabular}


These measurements show that though the initial advantage was in faror of group 2, the increase in height made by group 1 in the first six months after transplanting was more than three times that made by group 2. In the first year the average height per tree for group 1 increased 11 inches, while that for group 2 increased only 5.1 inches. That this more rapid growth of group 1 over group 2 continued throughout the first two years is shown by the increased difference at each measuring between the average height per tree for the two groups. At the end of the two years the new growth, as measured by the increase in height, made by the trees which had been set with their roots in a ball of earth from the nursery was more than 43 per cent greater than that made by those which were transplanted with their roots bare of earth. This increased growth and rigor is most certainly worth a little extra labor and expense.

The effect of the two different methods of transplanting was equally pronounced on the early yield of the trees. No trees whatever were lost in the first year. Of the 156 trees comprised in group 1,53 trees, or 34 per cent, fruited at one year from setting, while of the 165 trees comprised in group 2, only three trees, or 2 per cent, fruited. As the first crop is usually small, it was not measured.

In the course of the second year, one tree was lost from group 1 and seren trees were lost from group 2. At two years from setting, 148 of the 155 trees of group 1 , or 95 per cent, were fruiting, while of the 158 trees of group 2, only 134 trees, or 85 per cent, produced fruit. The crop from each group was measured in unpulped coffee cherries and is shown in Table III.

TABLE. III.- Yield of san Ramon coffee at two years from setting.

\begin{tabular}{|c|c|c|}
\hline \multirow{2}{*}{ Date of piching. } & \multicolumn{2}{|c|}{ Yield of coffee cherries. } \\
\hline & Group 1. & Group 2. \\
\hline $\begin{array}{l}\text { Aug. } 18,1916 \ldots \ldots \\
\text { Aug. } 30,1916 \ldots \ldots \\
\text { Sept. } 9,1916 \ldots \ldots \\
\text { Sept. } 25,1916 \ldots \ldots \\
\text { Oct. } 3,1916 \ldots \ldots \\
\text { Oct. } 14,1916 \ldots \ldots \\
\text { Oct. } 26,1916 \ldots \ldots \\
\text { Nov. } 6,1916 \ldots \ldots \\
\text { Nov. } 17,1916 \ldots \ldots \\
\text { Nov. } 29,1916 \ldots \ldots \\
\text { Dec. } 12,1916 \ldots\end{array}$ & $\begin{array}{r}\text { Liters. } \\
1.2 \\
1.1 \\
3.0 \\
6.1 \\
7.0 \\
9.9 \\
7.4 \\
11.5 \\
9.5 \\
7.1 \\
13.1\end{array}$ & $\begin{array}{r}\text { Liters. } \\
0.1 \\
.4 \\
.9 \\
2.1 \\
2.2 \\
3.2 \\
2.8 \\
5.2 \\
4.7 \\
2.8 \\
5.4\end{array}$ \\
\hline . Total..... & 76.9 & 29.8 \\
\hline
\end{tabular}

In not a single picking did the yield from the second group approximate that from the first. For group 1 the total yield amounted to 76.9 liters, and for group 2, 29.8 liters, or less than two-fifths as much as that of group 1. Here again the very marked influence of 
the method of transplanting is clearly shown in a much increased yield from those trees which were transplanted with their roots incased in the soil from the nursery. It is reasonable to suppose that the difference in crop will not stop with this record, but will show up in the future, since the difference in development of the two groups is still evident.

\section{SUMMARY OF RESULTS OF THE TESTS.}

Under the conditions of the experiments coffee seedlings with only five to six pairs of leaves, when transplanted with the roots incased in a ball of earth from the nursery, show little difference in early growth and yield as a result of transplanting from those transplanted with roots bare of earth; provided the latter transplanting is properly done.

By leaving the seedlings in the nursery a year longer than the above a more even stand may be obtained, since the plants are then thriftier and better able to cope with unfavorable conditions. That the nursery may be kept in condition at a cost considerably less than that of caring for the trees after transplanting is also a factor which makes it advisable to leave the seedlings in the nursery until the second rainy season after planting the seed.

When the seedlings are transplanted from the nursery to the plantation at approximately 18 to 20 months after planting the seed, a cousiderably earlier growth and increased yield may be expected to result from transplanting with the roots incased in the block of soil in which the seedlings have grown in the nursery rather than with the roots free of soil. This difference should be considerably greater in the average planting than in the experiments reported, since in the latter care was taken to avoid breaking and drying out the roots of those plants which were remored without soil, a precaution not always observed in ordinary plantation practice.

At the end of one year, in the first test reported, the trees transplanted with their roots incased in the soil in which they had grown measured 35 per cent more in height than the check, and at the end of two years, 23 per cent more than the check. Their yield the second year was double that of the check.

In the second test the increased growth for the first year was nearly 12 per cent greater for the trees transplanted with roots in earth than that of the check. while their yield the second year was three times as great as that of the check.

In the third experiment the increase in height for trees so transplanted was 43 per cent greater than that of the check at the end of two years. At one year from setting $3+$ per cent of the former fruited against 2 per cent of the check trees. At two years from setting $9 \breve{5}$ per cent of the trees transplanted with roots in a ball 
of earth fruited as against 85 per cent of the check trees. The crop from the former, tree for tree, considerably more than doubled that from the latter, whether the fruiting trees only are considered or the entire planting.

These plantings indicate a definite method of obtaining a more rapid derelopment of the coffee tree and a large increase in early yields.

\section{RECOMIMENDATIONS.}

The following method of handling young coffee seedlings is recommended:

Mature seed, selected from trees of desirable types, may be planted immediately after pulping or may be washed free of the slimy coating and kept well spread out in an airy shaded place for a period not longer than three or four months previous to planting. ${ }^{1}$ Excessive drying must be aroided, as this will destroy the viability of the seed.

The seed should not be planted deeply, a quarter of an inch of soil being a sufficient covering. The seed may be sown in the nursery or in boxes from which they can be transplanted to the nursery when the cotyledonous leaves have hardened. Previous to germination the soil should not be allowed to dry out. In the nursery the seedlings should not be less than 8 inches apart. Here they may remain until the second rainy season after planting.

Too dense shading or an exposure to too full sunlight should be avoided, as either extreme is injurious to the best derelopment of the young plants.

Provided the soil and exposure throughout the projected planting are farorable, numerous small scattered nurseries are preferable to fewer and larger ones, and they greatly facilitate the transportation of the trees at the time of planting.

Transplanting of moderately large coffee seedlings either from or into a heary clay soil should unquestionably be done with the roots still incased in the soil in which they grew. Many roots are injured when the plants are taken out and freed from soil of this type, while on resetting plants in such soil it is difficult to secure a proper spread of roots or to fill in around them, especially if the clay is wet.

A heavy clay can be cut with the aid of a spade or a machete into blocks (Pl. I, fig. 1) easily carried without crumbling. If the soil is liable to crumble, it can be reinforced by wrapping large leaves around it. The trees with their blocks of earth should be placed immediately in a fiat tray or box, so arranged with a pole at either side that it can be carried by two men (Pl. I, fig. 2).

The trees are then carried to holes prepared in advance. ${ }^{2}$ The poorer the soil in which the planting is made, the greater the neces- 


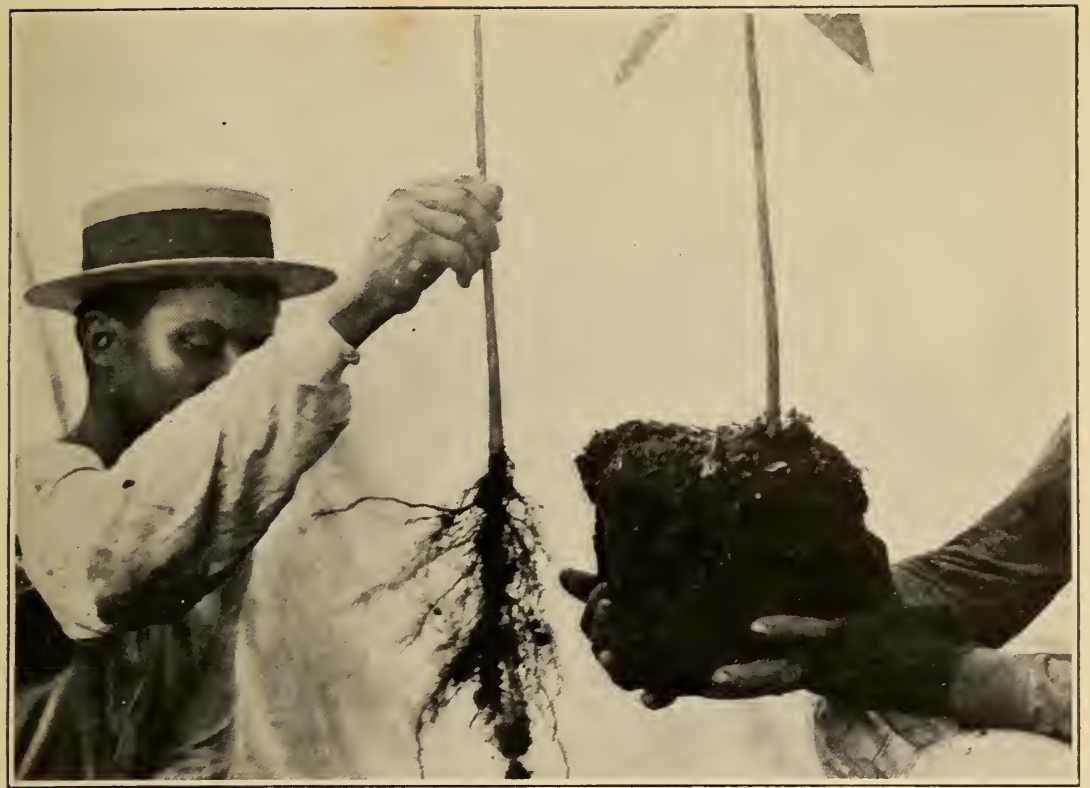

FiQ. 1.-Coffee Roots Bare AND IN BaLl of SoIL.

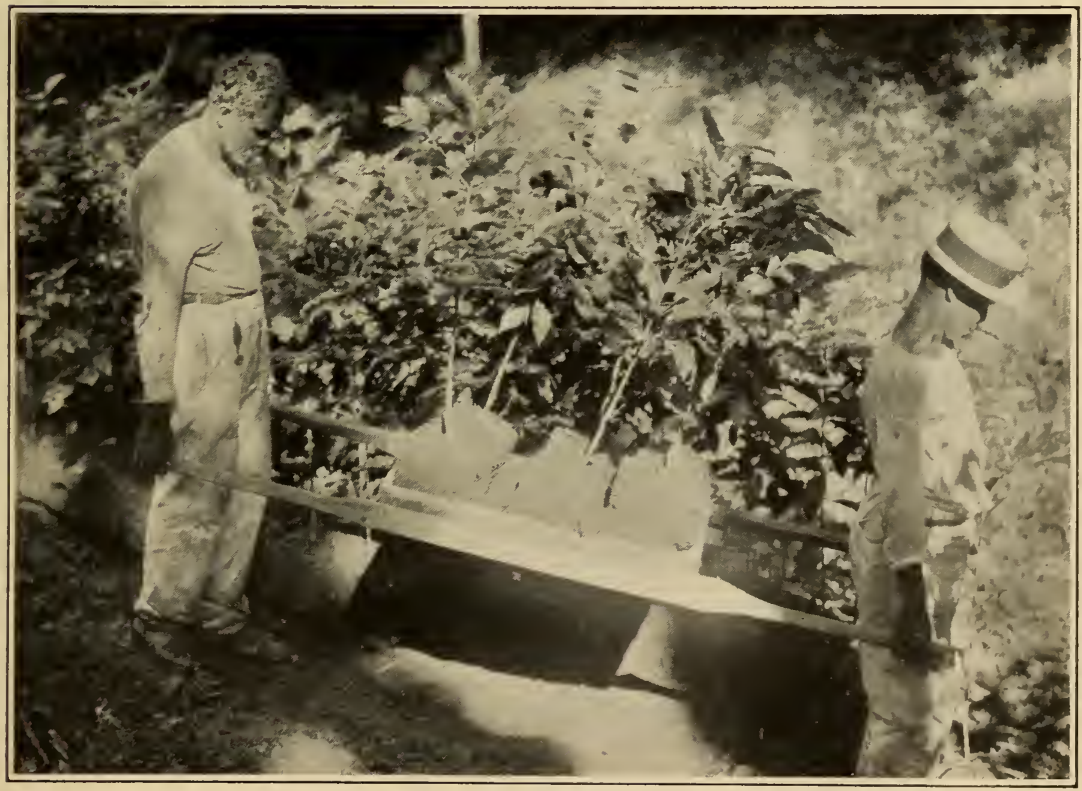

Fig. 2.-Carrying SEedlings from Nursery to field. 
sity for opening large holes to be filled with the best of the surface soil.

A very common practice, and one which is to be condemned, is that of setting a tree in a depression in which soil gradually accumulates, burying deeply those roots which should remain near the surface and facilitating the entrance of root fungi. The tree should be so set that in its permanent location it is no deeper than it was in the nursery, with the root collar just below the surface of the scii. If the earth has not been well compacted and well firmed around the newly set plant it will be apt to settle considerably below this level. 




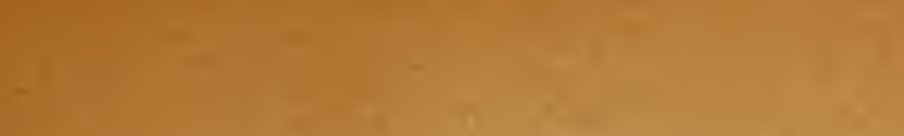

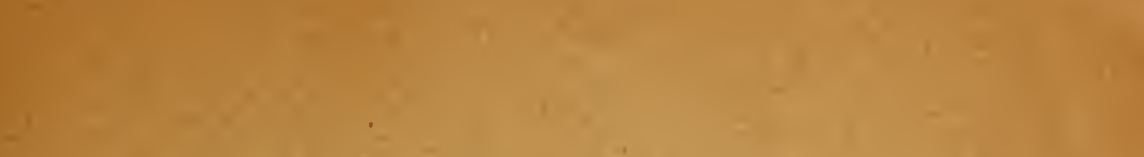

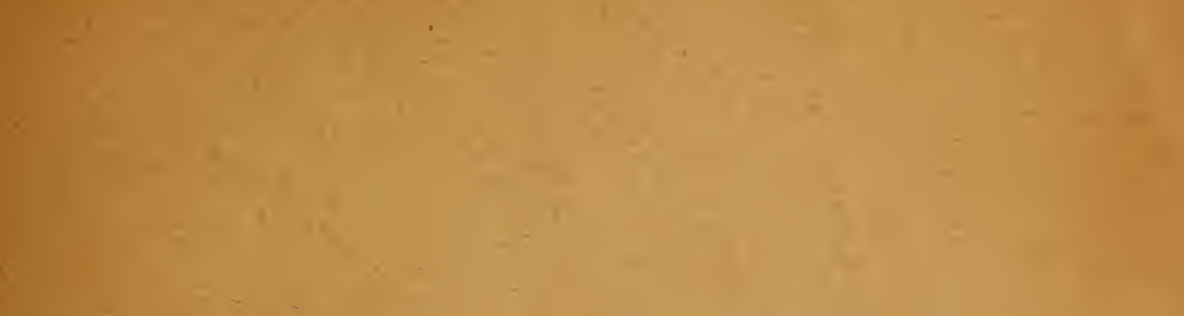

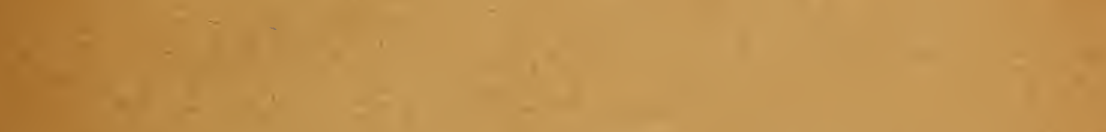

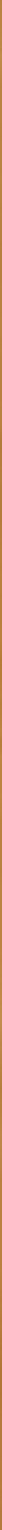


$\sin 19 \cdot 34$

UNIVERSITY OF FLORIDA

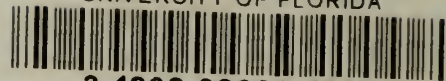

3 1262089291339

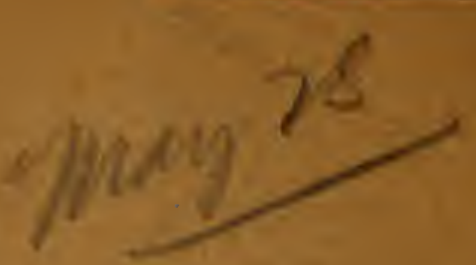

